\title{
Pendampingan Perintisan dan Pengelolaan Usaha Kelompok Cengkeh 1 Wirobrajan Yogyakarta
}

\author{
Purwani Retno Andalas ${ }^{* 1}$, Agustini Dyah Respati ${ }^{\# 2}$, Xaveria Indri \\ Prasasyaningsih ${ }^{\# 3}$, Putriana Kristanti ${ }^{\# 4}$ \\ ${ }^{*}$ Prodi Manajemen, Universitas Kristen Duta Wacana \\ \#3 Prodi Akuntansi, Universitas Kristen Duta Wacana \\ Jl. Dr. Wahidin Sudirohusodo No. 5-25, Yogyakarta \\ 1etnoandalas@gmail.com \\ 3indriprass@staff.ukdw.ac.id

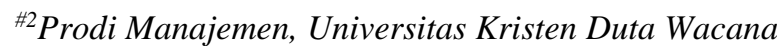 \\ Jl. Dr. Wahidin Sudirohusodo No. 5-25, Yogyakarta \\ 2agustini@staff.ukdw.ac.id

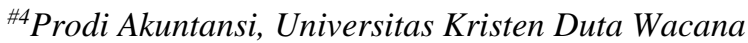 \\ Jl. Dr. Wahidin 5-25, Yogyakarta \\ 4putrianak@staff.ukdw.ac.id
}

\begin{abstract}
Abstrak-Pengabdian kepada masyarakat ini bertujuan mempersiapkan dan membekali para anggota kelompok mitra untuk merintis dan mengembangkan usaha terutama terkait dengan persiapan usaha dan pengelolaan dalam hal bauran pemasaran, organisasi dan pengelolaan keuangan. Pengabdian melingkupi pendampingan perintisan dan pengembangan usaha dari pelaku usaha dalam Kelompok Cengkeh 1, yang beranggotakan para ibu rumah tangga dengan berbagai ketrampilan membuat beberapa macam produk makanan. Periode pelaksanaan dimulai pada tanggal 6 Maret sampai dengan 14 Juni 2020. Metode yang diterapkan dalam pengabdian ini antara lain: melakukan analisis situasi, identifikasi permasalahan mitra, menentukan tujuan kerja, menyusun rencana pemecahan masalah, pendekatan sosial, pelaksanaan kegiatan, serta melakukan evaluasi terhadap kegaiatan dan hasil. Adapun hasil dari pengabdian ini antara lain adalah: terwujudnya usaha bersama dalam bidang kuliner, disertai adanya kesadaran dan pemahaman pengurus beserta anggota kelompok tentang pentingnya pengelolaan pemasaran, pengembangan organisasi, serta pengelolaan keuangan usaha maupun kelompok. Kelompok mitra sangat antusias untuk mengembangkan usahanya dan dari setiap anggota selalu berusaha untuk melakukan perbaikan produk dan layanannya. Pengabdian pendampingan kelompok ini memberikan manfaat ekonomis berupa adanya penghasilan tambahan bagi keluarga, peningkatan kreatifitas produksi, pemasaran, dan pelayanan. Masyarakat sekitarnya mendapatkan kemudahan dalam mendapatkan alternatif produk makanan yang dibutuhkan. Bahkan pada masa
\end{abstract}

pandemi ini kelompok mitra bersedia memberikan layanan antar produk bagi warga masyarakat sekitarnya.

Kata kunci: pendampingan, perintisan, pengelolaan, usaha, kelompok.

Abstract - This community service aims to prepare and equip members of partner groups to start and develop businesses, especially related to business preparation and management in terms of marketing mix, organization and financial management. This service includes mentoring in the pioneering and development of businesses in the Cengkeh 1 Group, which consists of housewives with various skills in making various kinds of food products. The implementation period starts from March 6 to June 14, 2020. The methods applied in this service include: conducting situation analysis, identifying partner problems, determining work goals, developing problem solving plans, social approaches, implementing activities, and evaluating activities and results. The results of this service include: awareness and understanding of the management and group members about the importance of marketing management, organizational development, and business and group financial management. The partner group is very enthusiastic about developing its business and each member always tries to make improvements to their products and services. This group assistance service provides economic benefits in the form of additional income for the family, increased creativity in production, marketing, and services. The surrounding community has easy access to 
the alternative food products they need. Even during this pandemic, partner groups are willing to provide services between products for residents of the surrounding community.

Keywords: assistance, pioneering, management, business, group

\section{Pendahuluan}

\section{A. Analisis Situasi}

Kelompok dasa wisma Cengkeh 1 berdomisili di Kawasan Rt 12, RW 03. Kalurahan Wirobrajan,Kecamatan Wirobrajan, Kota Yogyakarta. Domisili kelompok tersebut berada di kota yang cukup strategis, dalam arti mudah dijangkau, sarana transportasi umum mudah didapatkan dan jarak untuk mengakses sumberdaya relatif terjangkau.

Dengan anggota 10 orang ibu, secara geografis bertempat tinggal di satu deret pada sebuah gang yang berurutan sehingga mereka berinteraksi secara intensif dalam kehidupan keseharian. Intensitas relasi mereka dilakukan dalam pertemuan-pertemuan seperti kegiatan PKK, arisan, kegiatan Posyandu dan kegiatan kegiatan social yang lain.

Dalam kelompok ini, terdapat 7 orang ibu yang belum memiliki kegiatan yang produktif.

Profil singkat ibu ibu anggota dasa wisma Cengkeh 1 kami sajikan dalam tabel I berikut:

TABEL I

PROFIL KELOMPOK CENGKEH1

\begin{tabular}{|l|l|c|c|}
\hline No & \multicolumn{1}{|c|}{ Profil } & Jumlah & Total \\
\hline 1 & Gender: & 10 & \\
& Perempuan & - & 10 \\
& Laki-laki & & \\
\hline 2 & Usia : -40 & 4 & \\
& $30-50$ & 2 & 10 \\
& $>40-5$ & \\
& $>50$ & 2 & \\
\hline 3 & Pekerjaan: & 7 & 10 \\
& ASN & 1 & \\
& Ibu Rumah Tangga & & 10 \\
& Karyawati Swasta & 5 & \\
\hline 4 & Pengalaman usaha: & 5 & \\
& Ya & & \\
& Tidak & & \\
\hline
\end{tabular}

\section{B. Identifikasi Permasalahan Mitra}

Masa pandemi yang berkepanjangan berdampak pada pekerjaan para suami yang kemudian mengakibatkan menurunnya penghasilan untuk memenuhi kebutuhan keluarga. Oleh karena itu, para ibu merasa sangat perlu untuk melakukan kegiatan yang dapat menghasilkan pendapatan.

Merintis usaha bersama dalam kelompok Cengkeh 1, dipandang sebagai alternatif solusi bagi kondisi ekonomi mitra, karena mereka memiliki ketrampilan dan pengalaman yang cukup untuk mengolah makanan. Namun demikian, masalah yang masih ada pada kelompok ini adalah minimnya pengetahuan dan ketrampilan pengelolaan usaha kelompok, dan pengetahuan manajemen pemasaran serta pencatatan keuangan. Hal ini menimbulkan keragu raguan kelompok mitra untuk memulai usahanya.

Program Kemitraan Masyarakat (PKM) ini diharapkan dapat membantu menyelesaikan masalah pengelolaan usaha tersebut, sehingga dapat menjaga keberlanjutan usaha.

\section{Tinjauan Pustaka}

Kelompok merupakan keterikatan dua orang atau lebih yang berinteraksi dan saling tergantung serta melakukan aktivitas bersama untuk mencapai tujuan yang ditetapkan bersama [1]. Dalam masyarakat kelompok sering digunakan untuk pemberdayaan masyarakat. Namun, kelompok juga dapat didirikan oleh beberapa orang yang mempunyai keinginan untuk mengembangkan usaha secara bersama-sama [2]. Tujuan membentuk kelompok antara lain meningkatkan usaha setiap nanggota kelompok, membagikan pengalaman dan informasi untuk kemajuan bersama, membangun sinergi diantara anggota kelompok untuk mencapai tujuan, dan memudahkan pengajuan modal [3]. Kelompok tidak terbentuk secara otomatis, tetapi dalam proses pembentukannya, diawali dengan adanya kebutuhan atau perasaan yang sama dari individu yang terlibat. Individu atau anggota yang terlibat dalam kelompok usaha ini adalah pemangku kepentingan utama atas kelompok. Pemangku kepentingan utama adala orang atau kelompok yang memiliki pengaruh besar atas keputusan yang dibuat oleh kelompok [4]. Sebagai pemangku kepentingan utama, anggota kelompok ini mencurahkan pengetahuan, keterampilan, kemampuan teknis, kemampuan manajerial dan pengalamannya untuk kelompok agar kegiatan terlaksana dengan baik.

Gibson menjelaskan tahap pembentukan kelompok meliputi beberapa tahap, yaitu: [5]

1) Forming atau pembentukan: Anggota mulai saling mengenal, menerima diri mereka sebagai bagian grup.

2) Storming atau mempeributkan: Anggota kelompok mulai menerima keberadaan grup, namun masih muncul pertentangan atau konflik dalam kepemimpinan.

3) Norming atau tahap penyusunan norma: Tahap ini ditandai dengan adanya kesepakatan dan konsensus, hubungan yang dekat dan kompak.

4) Performing atau tahap mengerjakan: Kelompok mulai memusatkan tenaga untuk menjalankan tugas dan peran masing-masing, sehingga mampu menyelesaikan pekerjaan secara lancar, efisien, dan efektif.

Agar kelompok produktif dan berkinerja baik secara individu maupun kelompok, maka dalam kelompok diperlukan adanya karakteristik: tidak individualis, fleksibel, kontributif, komitmen bersama, komuniasi yang 
baik, saling percaya, kepemimpinan yang sesuai, dukungan internal, keterampilan yang relevan, mau terus belajar, dan tujuan yang jelas [7] [8]. Tujuan yang jelas memudahkan anggota kelompok memahami, dan akan berkomitmen tinggi untuk mencapainya. Kebutuhan sumberdaya manusia akan sejalan dengan perkembangan usaha kelompok. Pada tahap awal kebutuhan sumberdaya manusia masih dapat dipenuhi dari jumlah anggotanya sendiri. Namun seiring perkembangan kegiatan kelompok, maka diperlukan perencanaan kebutuhan akan sumberdaya manusia untuk mendukung kegiatan tersebut. Sumber daya manusia merupakan faktor penting dalam suatu usaha maupun kelompok usaha. Terlaksananya aktivitas usaha, tercapainya target penjualan dan terpenuhinya kinerja usaha kelompok itu melalui sumberdaya manusia [9]. Perencanaan kebutuhan sumberdaya manusia merupakan bagian dari proses manajemen sumber daya manusia untuk menjamin usaha memiliki sumberdaya manusia yang berkualitas dalam menyelesaikan pekerjaan. Proses manajemen sumberdaya manusi meliputi tiga tahap utama yaitu:

- mengidentifikasikan dan menyeleksi karyawan yang kompeten

- memberikan ketrampilan dan pengetahuan terkini

- mempertahankan karyawan yang kompeten dan berkinerja tinggi.

Selanjutnya, penentuan kebutuhan tenaga kerja atau sumberdaya manusia yang diperlukan kelompok usaha dimulai dengan menyusun diskripsi dan spesifikasi kerja sehingga tenaga kerja. Deskripsi kerja merupakan suat pernyataan tertulis yang menguraikan secara rinci suatu pekerjaan. Deskripsi kerja mencakup muatan tugas, lingkungan kerja, dan konndisi pekerjaan. Dengan demikian deskripsi kerja akan menjadi panduan kerja karyawan. Sedangkan spesifikasi kerja adalah pernyataan tertulis tentang kualifikasi minimum yang harus dipenuhi seseorang agar dapat dengan baik menangani pekerjaaan yang diberikan. Dari spesifikasi pekerjaan tersebut daat diidentifikasi kemampuan dan sikap kerja yang diperlukan agar pekerjaaan dapat diselesaikan dengan efektif dan efisien [8].

Pencatatan dan pengelolaan keuangan bagi usaha bisnis maupun kelompok sangat dibutuhkan. Penerapan sistem pencatatan dan pengeloaan keuangan akan bermanfaat dalam menjaga dan mengembangkan usaha, menghindari kelalaian yng dapat kita, rekan usaha atau pegawai lakukan dalam hal keuangan [10].

Beberapa buku catatan yang perlu dimiliki adalah: buku kas, buku piutang, buku persediaan barang, buku inventaris, buku utang, dan buku modal [11]. Selain buku-buku tersebut juga perlu dibuat laporan keuangan, antara lain: Laporan Posisi Keuangan, Laporan Laba Rugi, dan Catatan atas Laporan Keuangan [12].
Untuk meningkatkan daya tarik pasar, dalam kajian mikro-ekonomi yang dikembangkan oleh Porter, terdapat 5 kekuatan yang menentukan. Kekuatan kekuatan perusahaan ini mempengaruhi kemampuannya untuk melayani pelanggan dan memperoleh keuntungan. Perubahan dalam salah satu kekuatan mengharuskan perusahaan untuk menilai ulang pasarannya. Lima kekuatan utama dan strategi bersaing tersebut meliputi: [13] [14].

- daya tawar pelanggan

- daya tawar pemasok

- ancaman pendatang baru

- ancaman produk pengganti

- intensitas persaingan

Strategi bersaing merupakan pendekatan perusahaan yang intensif untuk memenangkan setiap bisnisnya. Strategi yang dapat dipilih meliputi:

- $\quad$ strategi kepemimpinan biaya (cost leadership strataegy)

- strategi diferensiasi produk (product differentiation)

- $\quad$ strategi fokus (focused strategy)

\section{Tujuan Pengabdian}

Pengabdian ini bertujuan untuk memberikan edukasi pemahaman dan pendampingan dalam menerapkan manajemen usaha, yang meliputi manajemen sumberdaya manusia, manajemen keuangan dan manajemen pemasaran untuk merintis usaha. Dengan demikian, kelompok mitra dapat mewujudkan suatu rintisan usaha, dan mampu mengelola usaha tersebut secara berkesinambungan.

Sebagai usaha kelompok, mitra perlu untuk membangun suatu kelompok yang solid, maka dalam pengabdian ini juga bertujuan untuk memberikan motivasi dan pendampingan dalam mengelola dinamika kelompok usaha.

\section{Metoda PELAKSANAAN}

Metode yang digunakan dalam Pengabdian kepada Masyarakat (PKM) ini adalah dengan pola atau sistem yang dilakukan dalam menjalankan kegiatan pengabdian kepada masyarakat yang meliputi tahapan-tahapan sebagai berikut:

\section{A. Identifikasi Masalah}

Identifikasi masalah merupakan hasil dari tahap analisis situasi. Permasalahan yang dihadapi oleh kelompok sasaran pengabdian yang akan ditangani melalui kegiatan pengabdian kepada masyarakat ini. Persoalan utama yang dihadapi mitra saat ini adalah perlunya perintisan dan pengelolaan usaha kelompok untuk mewujudkan kegiatan yang produktif.

Masalah yang dihadapi mitra dalam bidang manajemen adalah : 
- manajemen sumberdaya manusia, terutama untuk memenuhi kebutuhan tenaga kerja untuk menjalankan usaha

- manajemen keuangan dan akuntansi yang belum difahami oleh kelompok mitra

- strategi pemasaran untuk memberikan kepuasan kepada konsumen dan mengatasi tantangan persaingan

Masalah yang akan dibenahi untuk merintis dan mengelola usaha kelompok , yaitu:

- pembentukan kelompok sebagai awal untuk melakukan rintisan usaha

- menentukan kebutuhan tenaga kerja, dengan menyusun deskripsi dan spesifikasi pekerjaan

- pengelolaan keuangan terkait dengan pencatatan, pengelolaan dan laporan keuangan

- manajemen pemasaran, terutama dalam hal pengembangan produk, penetapan harga, pemilihan tempat usaha dan cara berpromosi untuk menghadapi tantangan persaingan dan adanya perubahan perilaku masyarakat dalam memenuhi kebutuhan makanan sebagai akibat pandemi Covid 19.

\section{B. Menentukan Tujuan Kerja}

Tujuan kerja ditentukan secara spesifik, yaitu suatu perubahan yang ingin dicapai melalui kegiatan PKM yang akan dilaksanakan. Kondisi setelah dilakukannya kegiatan harus dapat dibedakan dengan kondisi sebelum dilakukan kegiatan pengabdian. Tujuan kerja dari program PKM ini adalah perintisan usaha kelompok, penyusunan sistem pengelolaan keuangan dan pengelolaan pemasaran, yaitu:

- terbentuknya kelompok mitra yang akan menjalankan usaha bersama dengan mekanisme kerja yang disepakati

- kelompok usaha memiliki pembagian kerja yang tepat dan mendukung kelancaran usaha

- kelompok usaha memiliki dan melaksanakan system pengelolaan, pencatatan dan pelaporan keuangan yang baik

- kelompok usaha memiliki rencana pemasaran yang mencakup bauran produk, penentuan harga, teknik promosi dan layanan kepada konsumen

\section{Rencana dan Pelaksanaan Pemecahan Masalah Tahap rencana terdiri atas sub-tahapan, sebagai} berikut:

3) Mencari Alternatif Pemecahan Masalah: Berbagai alternatif pemecahan masalah yang dikembangkan, antara lain: sosialisasi dan penyuluhan tentang pentingnya membangun kerjasama kelompok, penentuan sumberdaya manusia yang tepat baik dalam jumlah maupun kualitas, penyusunan istem pencatatan dan pelaporan keuangan dan strategi bauran pemasaran.

4) Memilih alternatif yang terbaik: Program PKM ini memilih untuk memecahkan masalah mitra melalui:

- penyuluhan partisipatif dengan tujuan kelompok memiliki kekompakan dan Kerjasama yang solid

- sosialisasi dengan tujuan kelompok memiliki pemahaman tentang lingkungan usaha

- sarasehan bersama-sama agar kelompok memiliki rencana usaha yang tepat dan baik

- pelatihan dengan tujuan meningkatkan ketrampilan dan kemampuan dalam menerapkan manajemen usaha

- pendampingan dengan tujuan untuk memastikan bahwa usaha kelompok berjalan dengan baik.

\section{Pendekatan Sosial}

Pendekatan sosial dimaksudkan sebagai pendekatan terhadap masyarakat sasaran atau mitra pengabdian. Mitra sasaran diposisikan sebagai subyek dari kegiatan pengabdian ini. Kelompok mitra sebanyak-banyaknya dilibatkan dalam kegiatan, termasuk dalam proses perencanaan kegiatan. Semua pihak yang akan menjadi subyek program pengabdian ini dijadikan sasaran pendekatan. Kelompok mitra ditumbuhkan kesadarannya bahwa masalah itu adalah masalah mereka, yang perlu untuk dipecahkan sendiri atau bersama pihak lain.

Pendekatan sosial dalam program PKM ini dilakukan melalui pendekatan sosial dengan melibatkan seluruh komponen kelompok mitra dan para pemangku kepentingan yang merupakan bagian dari lingkungan sosial mitra program ini.

\section{E. Pelaksanaan Kegiatan}

Pada tahap pelaksanaan, kegiatan yang akan segera dilakukan direncanakan secara matang dan terinci, dengan menentukan:

- bentuk kegiatan yang akan dilakukan,

- waktu pelaksanaan kegiatan,

- tempat pelaksanaan kegiatan,

- pihak-pihak yang akan dilibatkan dalam kegiatan.

Dalam penentuan pelaksanaan kegiatan tersebut pendapat dan saran dari kelompok sasaran sangat perlu diperhatikan.

\section{F. Evaluasi Kegiatan dan Hasil}

Evaluasi kegiatan dalam setiap tahapan serta upaya penyempurnaan dilakukan selama proses pelaksanaan pengabdian berlangsung. Evaluasi mengikutsertakan kelompok mitra. Proses ini merupakan bentuk 
pertanggungjawaban dari segala sesuatu yang telah dilakukan dalam program pengabdian kepada masyarakat.

\section{TARGET DAN LUARAN}

Target kegiatan pengabdian ini adalah terwujudnya rintisan usaha kelompok mitra, yaitu berupa usaha kuliner dengan konspe angkringan.

Target kegiatan tersebut ditentukan secara bersamasama dengan mitra, berdasarkan kebutuhan mitra. Masa pandemi membuat kelompok mitra membutuhkan kegiatan yang produktif untuk menopang kebutuhan ekonomi keluarga. Melalui kegiatan ini mitra dapat mengatasi masalah yang dihadapi, melalui kegiatan usaha bersama.

Luaran dari kegiatan pengabdian ini antara lain adalah: (1) sebuah system dan mekanisme operasi kegiatan usaha angkringan (2) bahan pembelajaran dan laporan pengabdian.

\section{HASIL DAN PEMBAHASAN}

\section{A. Kegiatan}

Beberapa kegiatan yang sudah dilaksanakan pada kegiatan pengabdian ini adalah:

(1) menyampaikan kepada kelompok mitra tentang pelaksanaan dan manfaat dari program PKM ini,

(2) melakukan sosialisasi dan diskusi tentang pentingnya pembentukan kelompok usaha

(3) menyusun rencana usaha dengan kelompok mitra

(4) melakukan penyuluhan partisipatif tentang strategi pemasaran

(5) mendiskusikan dengan kelompok mitra tentang rencana bauran pemasaran

(6) menyelenggarakan workshop perencanaan kebutuhan sumberdaya manusia

(7) menyelenggarakan pelatihan dan workshop tentang pengelolaan, pencatatan dan pelaporan keuangan (akuntansi)

(8) menyelenggarakan sarasehan dengan kelompok mitra untuk memperoleh informasi dan melakukan identifikasi tentang kekuatan, kelemahan, hambatan/ancaman dan peluang yang dihadapi,

(9) melakukan pendampingan dan evaluasi dalam perintisan usaha

(10) mengadakan pertemuan dengan kelompok mitra untuk menyampaikan kesimpulan dan saran dari pelaksanaan PKM yang telah dilakukan.

Tabel 2 menyajikan ringkasan dari masalah, kegiatan, dan hasil yang dicapai oleh PKM ini.

TABEL 2

MASAlaH, KEGIATAN DAN HASIL

\begin{tabular}{|c|c|c|c|c|}
\hline No & $\begin{array}{l}\text { Sebelum } \\
\text { PKM }\end{array}$ & Kegiatan & $\begin{array}{l}\text { Sesudah } \\
\text { PKM }\end{array}$ & $\begin{array}{c}\text { Indikator } \\
\text { hasil }\end{array}$ \\
\hline 1 & $\begin{array}{l}\text { Bidang SDM } \\
\text { : belum } \\
\text { memiliki } \\
\text { rencana } \\
\text { kebutuhan } \\
\text { baik dalam } \\
\text { jumlah } \\
\text { maupun } \\
\text { kualitas }\end{array}$ & $\begin{array}{l}\text { Pelatihan dan } \\
\text { workshop } \\
\text { untuk } \\
\text { menentukan } \\
\text { kebutuhan } \\
\text { karyawa dan } \\
\text { pengelola }\end{array}$ & $\begin{array}{l}\text { Mampu } \\
\text { menyusun } \\
\text { dan } \\
\text { menentu } \\
\text { kan jumlah } \\
\text { dan } \\
\text { kualifikasi } \\
\text { karyawan }\end{array}$ & $\begin{array}{l}\text { Memiliki } \\
\text { rencana } \\
\text { kebutuhan } \\
\text { karyawan } \\
\text { dan } \\
\text { pengelola }\end{array}$ \\
\hline 2 & $\begin{array}{l}\text { Bidang } \\
\text { Keuangan : } \\
\text { Belum } \\
\text { memiliki } \\
\text { sistem } \\
\text { pencatatan } \\
\text { dan laporan } \\
\text { keuangan }\end{array}$ & $\begin{array}{l}\text { Pelatihan dan } \\
\text { pendam- } \\
\text { pingan dlm } \\
\text { pengelolaan } \\
\text { dan } \\
\text { pencatatan } \\
\text { keuangan yg } \\
\text { baik }\end{array}$ & $\begin{array}{l}\text { Mampu } \\
\text { menyusun } \\
\text { catatan dan } \\
\text { laporan } \\
\text { keuangan } \\
\text { usaha }\end{array}$ & $\begin{array}{l}\text { Memiliki } \\
\text { sistem } \\
\text { pencatata } \\
\text { n dan } \\
\text { pelaporan } \\
\text { keuangan } \\
\text { yang } \\
\text { sesuai } \\
\text { akuntansi }\end{array}$ \\
\hline 3 & $\begin{array}{l}\text { Bidang } \\
\text { Pemasaran: } \\
\text { Belum } \\
\text { memiliki } \\
\text { rencana } \\
\text { pemasaran }\end{array}$ & $\begin{array}{l}\text { Pelatihan dan } \\
\text { pendam- } \\
\text { pingan dlm } \\
\text { penyusunan } \\
\text { program } \\
\text { pemasaran }\end{array}$ & $\begin{array}{l}\text { Mampu } \\
\text { menyusun } \\
\text { rencana } \\
\text { bauran } \\
\text { pemasaran } \\
\text { yang baik }\end{array}$ & $\begin{array}{l}\text { Memiliki } \\
\text { rancangan } \\
\text { program } \\
\text { bauran } \\
\text { pemasaran }\end{array}$ \\
\hline
\end{tabular}

\section{B. Dilaksanakannya Rencana Usaha}

Penyelenggaraan PKM ini menghasilkan terwujudnya rintisan usaha yang berjalan baik:

(1) Rintisan usaha dapat terwujud, berupa usaha kelompok dalam bidang kuliner dengan bentuk angkringan yang bernama "Angkringan Sorsawo".

(2) Pengelolaan sumberdaya manusia: terdapat pembagian tugas dengan deskripsi yang jelas, serta sesuai dengan spesifikasi yang dibutuhkan.

(3) Pengelolaan keuangan: dapat memenuhi kebutuhan dana, dengan pemanfaatan yang efisien dan efektif, disertai pencatatan yang baik dan benar.

(4) Manajemen pemasaran: menghasilkan dan memasarkan produk yang sesuai dengan kebutuhan dan selera konsumen, dengan harga yang bersaing dan memberikan layanan yang sesuai keinginan pelanggan, serta tempat usaha yang memadai.

\section{Tersusunnya strategi bersaing dan program bauran Pemasaran}

Berdasarkan sarasehan, pelatihan dan workshop yang telah dilakukan, maka telah dihasilkan suatu program bauran pemasaran untuk mendukung berjalannya usaha kelompok mitra.

Mengacu pada strategi bersaing menurut Porter, maka usaha kelompok mitra mengarah pada strategi untuk kepemimpinan/efisiensi biaya (cost leadership strategy), dengan harga murah sebagai alat utama dalam bersaing.

Adapun program bauran pemasaran yang disusun meliputi: 
(1) Kelengkapan produk makanan yang beraneka ragam dengan variasi menu yang terjadwal, dan selalu mencari alternatif menu yang baru, yang diolah secara higienis

(2) Harga yang ditetapkan dengan memperhatikan keterjangkauan, daya saing dan kesesuaian harga dengan kualitas produk

(3) Bauran promosi berkala, melalui media yang sesuai untuk menarik minat pembelian

(4) Tempat usaha yang bersih, nyaman dan adanya layanan pengantaran atau delivery service gratis untuk jarak tertentu yang dapat dijangkau.

\section{KESIMPULAN}

Kelompok mitra dapat mewujudkan rintisan usaha "Angkringan Sorsawo" dengan baik, serta mendapatkan respon positif dari lingkungan sekitar dan konsumen yang datang atau berbelanja makanan.

Usaha kelompok mitra telah dapat menerapkan prinsipprinsip pengelolaan usaha, baik dalam bidang sumberdaya manusia, keuangan dan pemasaran.

Rintisan usaha ini dapat menyediakan lapangan kerja bagi kelompok yang terlibat, dan memberikan alternatif tempat pembelian makanan bagi lingkungan sekitar dengan layanan yang baik.

Berdasarkan pengamatan selama pendampingan, maka usaha ini memiliki peluang untuk dikembangkan.

Mitra dalam pengabdian ini adalah anggota dan pengurus PWKI dalam wilayah propinsi DIY, yang semuanya adalah wanita, dan sebagian besar adalah ibu. Edukasi kepada para ibu ini diharapkan akan dapat meningkatkan kesejahteraan keluarga. Khususnya edukasi tentang pengelolaan aset keluarga. Pengetahuan akan menimbulkan dan menambahkan kesadaran dan tanggung jawab para ibu dalam mengelola aset milik keluarga.

Koordinasi anggota keluarga dalam mengelola asetnya akan meningkatkan kemanfaatan dari aset yang dimiliki oleh keluarga. Keluarga yang dapat mengelola asetnya dengan baik akan dapat memanfaatkan asetnya dengan baik pula, yang pada akhirnya akan mengarah pada meningkatnya kesejahteraan keluarga.

\section{UCAPAN TERIMA KASIH}

Terima kasih kepada Fakultas Bisnis Universitas Kristen Duta Wacana, yang telah membiayai pelaksanaan PKM ini pada tahun anggaran 2020 dengan Surat Tugas Pelaksanaan Pengabdian No 153/J-05/FBIS/2020

Terima kasih juga kami sampaikan kepada Kelompok Cengkeh 1 Wirobrajan yang telah bersedia menjadi mitra dari pengabdian ini.

\section{DAFTAR PUSTAKA}

[1] Robbins, P. Stephen, Perilaku Organisasi, Jakarta: Salemba Empat, 2017

[2] Schermerhorn, Management, Edisi 14, Singapore: Asia Edition, Wiley, 2020.

[3] Nakajima, Kan dan Takafumi Sasaki, Business group affiliation, corporate diversification, and cash holdings, Asia Pacific Journal of Management, doi.org/10.1007/s10490-020-09720-2. 27 Mei 2020.

[4] Wijaya, Nikodemus Hans Setiadi, Siti Al Fajar, Tri Hendro SP dan Conny Tjandra Raharja, Etika Bisnis: Panduan Bisnis Berwawasan Lingkungan bagi Profesional Indonesia, Yogyakarta: STIE YKPN, 2017.

[5] Gibson, James L., dan John M. Ivanchevich, James H. Donnaly, Jr and Robert Konospaske, Organization: Behavior, Structure Process, Boston: McGraw Hill, 2016.

[6] Osterwalder, Alexander dan Yves Pigneur, Business Model Generatipn, Jakarta: PT Elex Media Komputindo, 2017.

[7] Robbins, P. Stephen, Manajemen, Jakarta: Erlangga, 2016.

[8] Dessler, Garry, Human Resource Management, Edisi 15, New York: Pearson, 2020

[9] McShane, Organizational Behavior: Real Solution to Real Challenges, New York: McGraw Hill, 2021.

[10] Ferrel, O. C., Geofrey A. Hitt dan Linda Ferrel, Business Foundation: a changing world, New York: McGraw Hill, 2020.

[11] Najib, Amal, "Pencatatan keuangan untuk usaha kecil dan menengah tanpa repot", Kumparan, 27 November 2017. [Online] Tersedia: https://kumparan.com/amal-najib/pencatatan-keuanganuntuk-usaha-kecil-dan-menengah-tanpa-repot [Diakses: 6 Agustus 2020].

[12] IAI, Standar Akuntansi Keuangan: Pernyataan Standar Akuntansi Keuangan 19, Jakarta: Ikatan Akutansi Indonesia, 2016.

[13] Porter, Michael E., Competitive Advantage, LLC: Echo Point Books \& Media, 2019

[14] Margretta, J, Understanding Michael Porter: The Essential Guide to Competition and Strategy, LLC: Gildan Media, 2011. 